World Lumen Congress 2021 | May 26-30, 2021 | lasi, Romania

\title{
Internal Direction versus Outer Direction in Romanian and German Advertising
}

\author{
Patrick LAVRITS
}

https://doi.org/10.18662/wlc2021/34

How to cite: Lavrits, P. (2021). Internal Direction versus Outer Direction in Romanian and German Advertising. In A. Sandu (vol. ed.), Lumen Proceedings: Vol. 17 World Lumen Congress 2021 (pp. 349-359). Iasi, Romania: LUMEN Publishing House. https://doi.org/10.18662/wlc2021/34 


\title{
Internal Direction versus Outer Direction in Romanian and German Advertising
}

\author{
Patrick LAVRITS1
}

\begin{abstract}
People try to control and dominate their environment or are dominated by it. This is related to how they try to handle their existence. Personal, individual life is very important in cultures where selfcontrol is common. People are convinced that they can control nature by imposing their will. In cultures characterized by outer control, nature is considered much stronger than the individual. People see themselves as part of nature and want to live in harmony with nature. People believe that they cannot determine their own destiny, as it is influenced by external circumstances.
\end{abstract}

Keywords: interculturality; intercultural perception; internal direction vs. outer direction; advertising

\section{Introduction}

Modern, as well as more traditional societies, face the same basic problems. However, they differ in their answers and reactions to these challenges and how they solve these problems. This view was particularly widespread in social anthropology in the first half of the 20th century. To explain these differences between cultures, ethnologists like Edward T. Hall (1959) and social scientists like Geert Hofstede (1994) and Fons Trompenaars \& Charles Hampden-Turner (1996) developed so-called cultural dimensions.

With reference to these cultural dimensions, cultural patterns of thought, action and perception can be characterized, schematized and delimited. They reflect basic areas of possible cultural differences. However,

\footnotetext{
1 Lecturer, PhD, West University of Timisoara, Faculty of Economics and Business Administration, Romania, patricklavrits@yahoo.com
} 
a dimension always represents only one aspect of a culture, they are average values and never apply to all members of a culture. Moreover, different orientations can also be found within national cultures (e.g. in Belgium, Switzerland, Canada).

Fons Trompenaars is a Dutch researcher in the field of intercultural communication. He has published several books on the subject of intercultural management and, based on the works of Geert Hofstede and Edward T. Hall, developed a theory for analyzing cultural differences, which is described in his book Riding the Waves of Culture: Understanding Cultural Diversity in Business (1996) in the form of seven dimensions of cultural differences.

In contrast to Hofstede's study, the employees surveyed by Trompenaars (Trompenaars \& Hampden-Turner, 1996) do not come from a single company, but from many different companies. A large number of people were interviewed as part of intercultural training programs, and other people from international companies in 50 different countries were included. The respondents were presented with two or more statements, from which they could select the statement that was most relevant from their point of view (Schugk, 2004, p. 151). He published his findings and theories together with Charles Hampden-Turner in his major work Riding the Waves of Culture: Understanding Cultural Diversity in Business (Trompenaars \& Hampden-Turner, 1996). Within their research, they identified a total of seven basic cultural dimensions, which in turn can be classified into three categories of human problems. The first five cultural dimensions characterize the category of interpersonal relationships between the members of the culture. The last two dimensions, on the other hand, which describe the way in which time and the environment are dealt with, each form a category of their own.

\section{The characteristics of the cultural attitude towards the environment}

People try to control and dominate their environment or are ruled by nature. The way they deal with nature is directly related to how they try to handle their existence. This dimension emerges from geographical differences that influenced people's behaviour for a very long time, such as weather and climate conditions, plagues, reoccuring catastrophes etc. These conditions forced people into their specific fight of survival, generating behavioural codes.

Personal, individual life is the benchmark in cultures in which internal control predominates. People believe that they can control and rule 
the environment by imposing their will on it. They believe they can and have the right to dominate nature. This way of thinking however, refers not only to national environment, but also to the social one, namely the way how individuals work with teams and within organizations. The way they treat other people will be the same as they treat nature. This is the case, for example, in Anglo-Saxon countries and Northern Europe, but less so in German-speaking countries. They believe that by acting accordingly, they can influence their own fate. It is also important for them to receive constructive criticism where necessary, so that they can learn from it. Also, when having clear goals, they can be left largely free in their work. Members of these cultures tend to be proactive in making decisions. In principle, your fate can be influenced by will, conviction, inner attitude (internal direction), which is related to control over nature.

In cultures that are characterized by external control, nature is viewed much stronger than the individual. People see themselves as part of nature and want to live in harmony with the environment. Its laws, forces and effects influence human life in a considerable manner. People believe that nature controls them; they must work with their environment to achieve their goals. At work or in relationships, they focus their actions on others, and they avoid conflict where possible. People often need reassurance that they're doing a good job. This means that a manager has a lot of influence on the personnel. They believe in fate and see the reasons for successes and failures less in themselves than in the external circumstances (Treichel \& Mayer, 2011). This applies, for example, to African and Arab countries, but also to Russia and China. They think that they cannot determine their fate themselves, because it is predominantly influenced by external circumstances (outer direction).

The dimension of the environment has an impact on behavior and products in cultures. The songs sung by Frank Sinatra are proof of the United States's internal orientation. The song "My way" expresses independence from the environment. In the song "New York, New York", the artist also points to the high level of assertiveness of the Americans with "If I can make it there, I'll make it anywhere". The numerous super heroes in American comics are also an expression of an internal orientation.

An external orientation, on the other hand, relates to what is given from the outside. This external orientation is reflected in Asian martial arts such as ju-jitsu, aikido or judo (Treichel \& Mayer, 2011, p. 255). In Judo, for example, the opponent's movement is picked up so that the fighter follows the same direction of movement to allude to the opponent. The word do in Judo means "way of". You follow the way of the sword (Kendo) or the 
warrior (Bushido), their practices and disciplines, until they become part of your nature.

But this dimension is also expressed in the way we deal with the external environment. This can be demonstrated using the Walkman as an example. The original idea behind this Japanese invention is to listen to music without disturbing other people. This is in contrast to the normal motivation for using a Walkman in Europe and North America, where most users do not want to be disturbed by other people (Trompenaars \& Hampden-Turner, 2002, pp. 142-146).

In summary, the attitude towards the environment can be represented as follows: cultures of inner orientation are often dominant, sometimes aggressive towards the environment, conflict and resistance are considered to be signs of conviction, and there is discomfort when the environment appears out of control. Cultures of external orientation are often flexible, willing to compromise, geared towards peacefulness, harmony and empathy are very important and they can deal well with cycles or changes in nature.

\section{The attitude to the environment in German or Romanian society}

From my point of view, pessimism and fatalism describes the Romanians' inner worldview and shapes their attitude to active action. From this perspective, life is shaped by fateful predestination. They think that they cannot control their fate themselves, because it is influenced by external circumstances (outer direction). It seems that the tendency to passivity is expressed in the fact that one's own decisions are rather limited, personal initiative is hardly shown and responsibility for oneself is often transferred to others. They hope for a better life, but are aware that it will not happen in the long run. That is why they rely exclusively on short and medium-term plans and deals. This suggests that Romanians tend to be averse to longterm deals aimed at optimistic success in the future. At work or in relationships, they focus their actions on others, and they avoid conflict where possible.

In my opinion Germans identify strongly with their own professional activity. They take their work, their role, their task and their associated responsibilities very seriously. This suggests that they want to do what they do well and are very focused on it. Also, when having clear goals, they can be left largely free in their work. Members of these cultures tend to be proactive in making decisions. In principle, one's own fate can be 
influenced by will, conviction, inner attitude (internal direction), which is related to control over nature. If someone obeys the rules, he is considered reliable, correct and conscientious. Because structures, norms and rules are internalized here, there is also German reliability in relation to the matter. German products usually have a good reputation abroad and are often associated with high quality.

\section{The attitude to the environment in Romanian and German advertising}

Romanian culture tends to be outer directed when considering the attitude towards the environment. People want to live in harmony with nature and change it as little as possible. This is also shown in the numerous Romanian advertisements for mineral sparkling water (Bilbor, Dorna) or beer (Ciucaş, Ciuc, Gösser), in which the product is presented in nature and in harmony with nature (Fig.1).
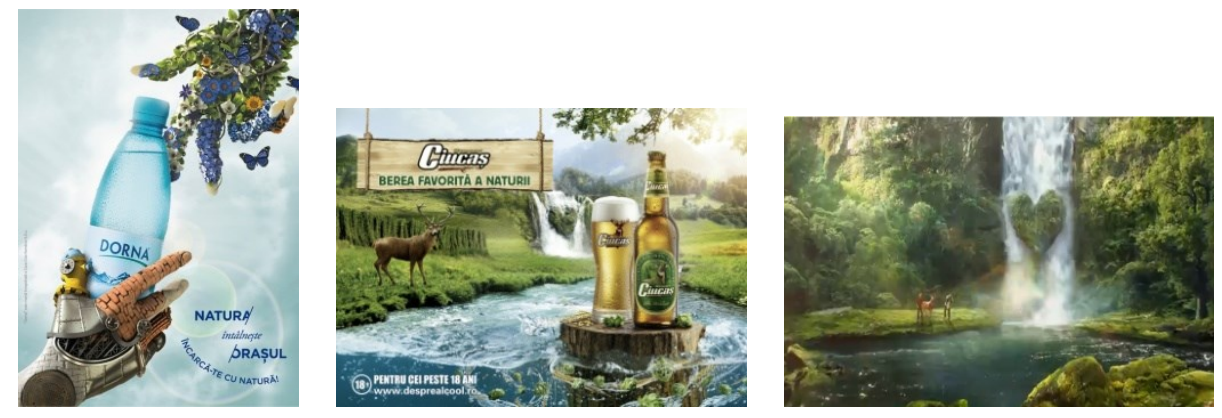

Fig. 1 Romanian advertisements highlighting the outward orientation of Romanian culture

The terms nature and naturalness often appear in the headlines and slogans of the advertisements (Dorna: "Nature meets the city"; Ciucass: "Nature's favorite beer" or "Beer from the mountains"; Gösser: "Of a perfectly naturalness."). In addition to the product, the eye-catchers of the advertisements usually present mountain landscapes and water sources, be it a waterfall or a mountain river or a lake, in order to emphasize the naturalness and purity of the drinks.

The product is also shown in the commercial for the beer brand Ciucaş within the framework of an idyllic mountain landscape (Fig. 2). A 
beautiful natural landscape is shown, in which the symbol of the beer brand, the deer, is shown next to the people. The paradisiacal mountain landscape with densely forested mountain slopes and a mountain river with a waterfall reproduces the harmony with nature. Of course, wildlife also belongs to nature, just like the deer, the symbol of the Ciucass beer brand. Once at the river, people and deer can admire the three elf-like women who throw the aromatic hops and the ripe malt into the water, thus imitating the brewing process of "nature's favorite beer". It is a paradisiacal landscape in which humans, animals and nature live together in harmony and offer the possibility of enjoyment, tranquility but also purity. A beer from nature and in nature can be enjoyed alone, but above all with friends (also a characteristic of a collectivist society).
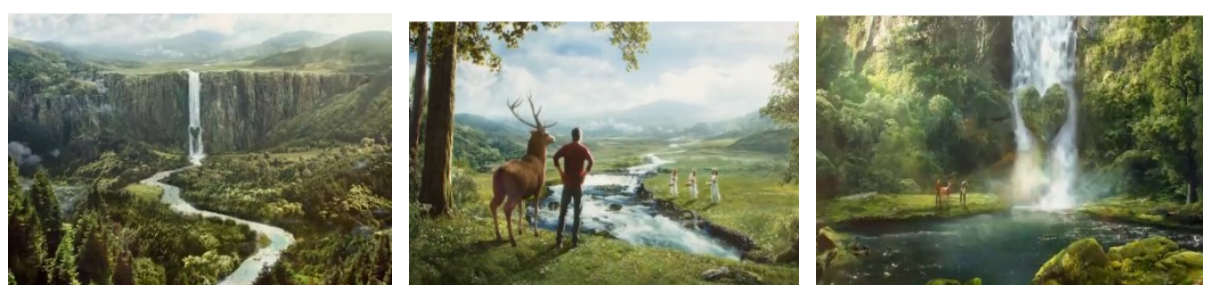

Fig. 2 Advertising film for the Ciucaş beer brand - Nature's favorite beer (2013)

In Romanian commercials, the Garanti bank even uses talking animals to advertise the saving of the Şinca forest, e.g. the wolf Mişu, the bear Marinică or the lynx, who live in the forest and are in danger of losing their natural habitat (Fig. 3 ).
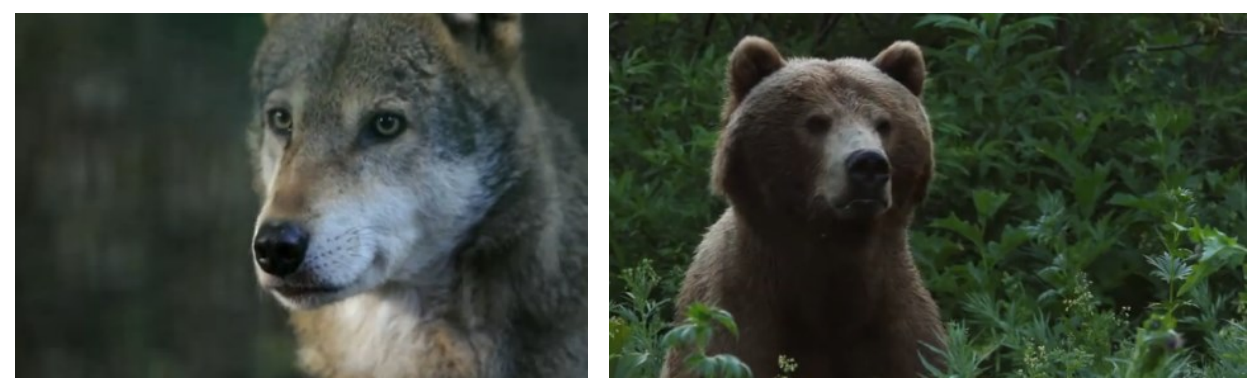

Fig. 3 Advertising film for Bank Garanti - on https://www.iqads.ro/creatie/20983/garanti-bank-lupul 
Many Romanian advertisements also draw attention to the dangers of environmental pollution and the extreme deforestation with sometimes brutal, shocking images to point out the extreme deforestation. The Botanical Garden in Bucharest advertises with the slogan: "We have been learning from nature for 150 years" against environmental pollution and the destruction of nature. Nature is seen as an important resource in which people should live balanced and carefree (Fig. 4).

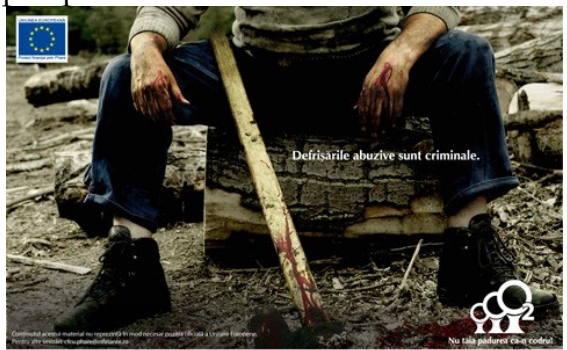

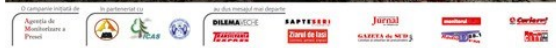

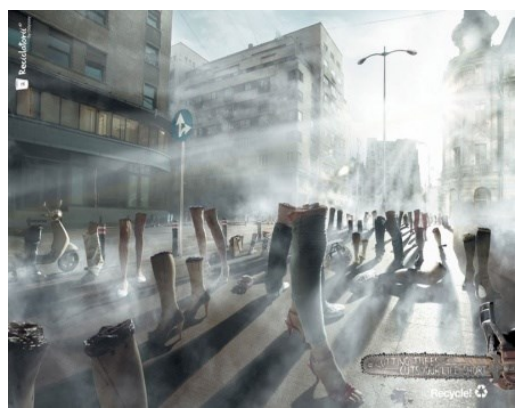

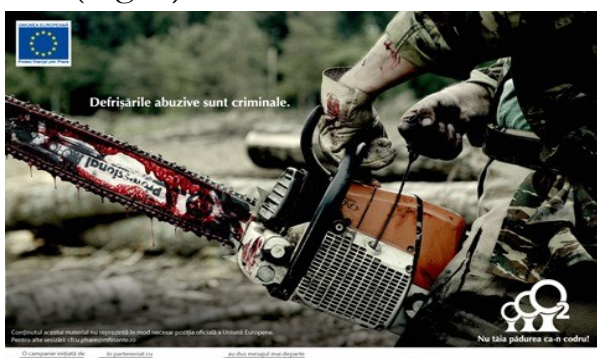
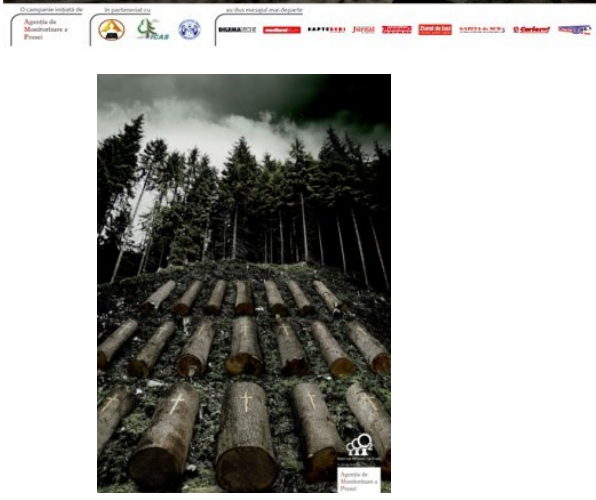

Fig. 4 Romanian advertisements indicating environmental pollution and destruction

In the Romanian commercial "Let's do it Romania", a family is having a picnic by the river (Fig. 5). When they start to eat, the father notices that the mustard bottle is empty. Then he simply throws the empty mustard bottle into the river, along with many other bottles and garbage that has been collected next to a tree in the river. As a result, the father asks a couple across the river to lend him their mustard bottle and toss it over. When they throw him the bottle, it falls into the river next to the other empty bottles and garbage. The father now tries to locate the borrowed bottle and thinks he has found it. But when he presses the mustard out of the bottle into the plate, nothing but dirty and contaminated water flows over his grilled meat. Angry, he just throws the wrong bottle away on another heap of garbage, which this time piles up not far from him. 

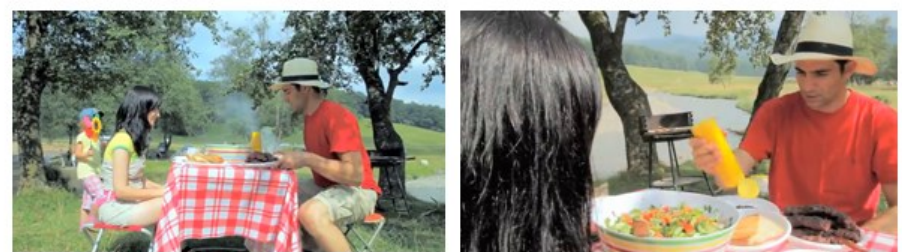

Abb. 199.1

Abb. 199.2

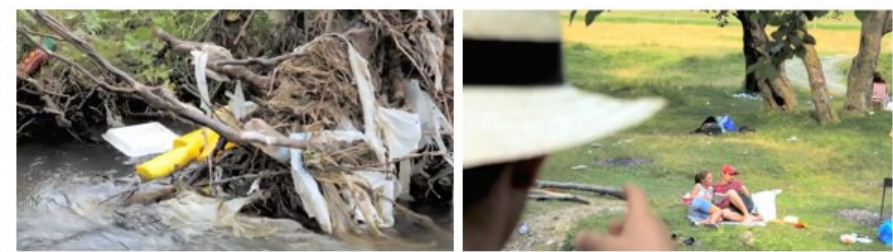

Abb. 199.3

Abb. 199.4
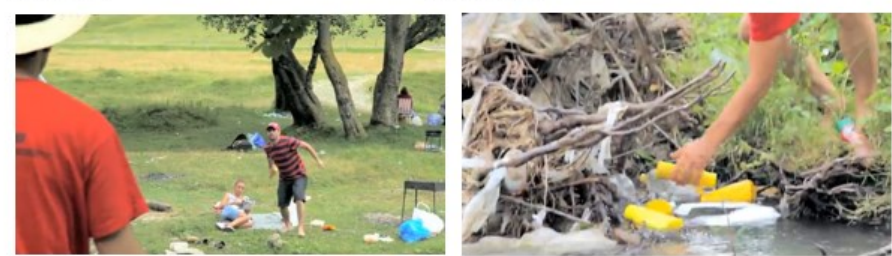

Abb. 199.5

Abb. 199.6
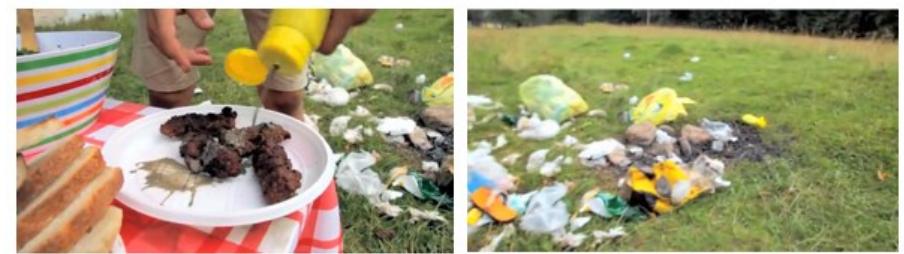

Fig. 5 Advertising film for Let's do it Romania - The Mustard (2010)

Superstition and belief in fate are also characteristics of an external orientation. Romanian advertisements and commercials often feature fortune tellers, horoscopes, lucky charms, such as a horoscope to choose the right profession or lucky charms such as a chimney sweep, a shamrock or a horseshoe. However, it is always pointed out that you don't just have to rely on these lucky charms when buying a used car or starting a career (Fig. 6). 

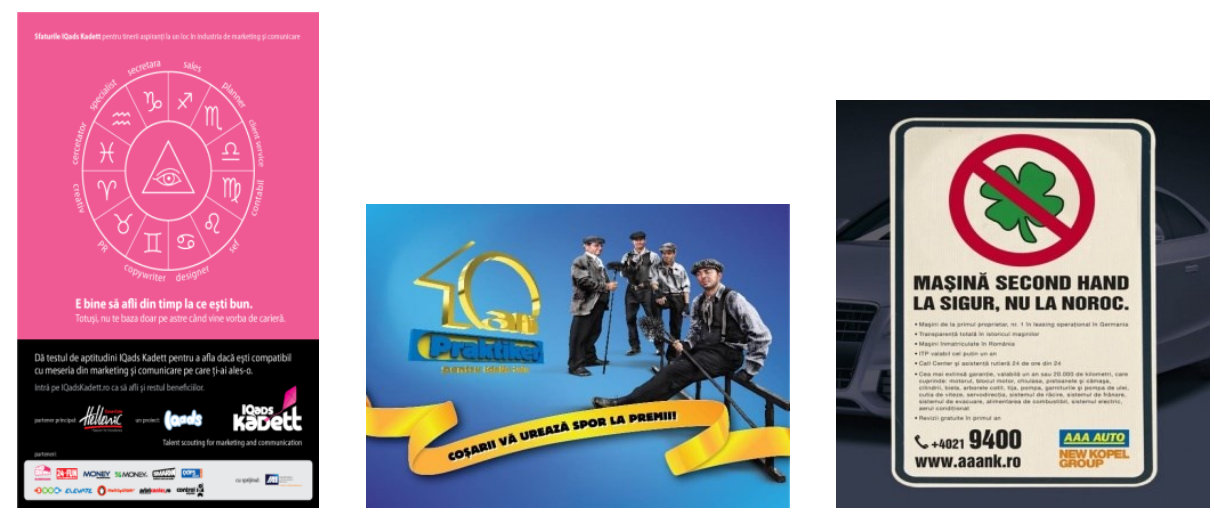

Fig. 6 Romanian advertisements indicating superstition and outward orientation

The German advertisement for "Caritas - poverty" shows the inner orientation of the Germans through the conquest of diseases (Fig. 7). Mankind conquered the plague, overcame smallpox, and developed drugs against tuberculosis and typhoid. But medicine alone cannot cope with the biggest pathogen: poverty.
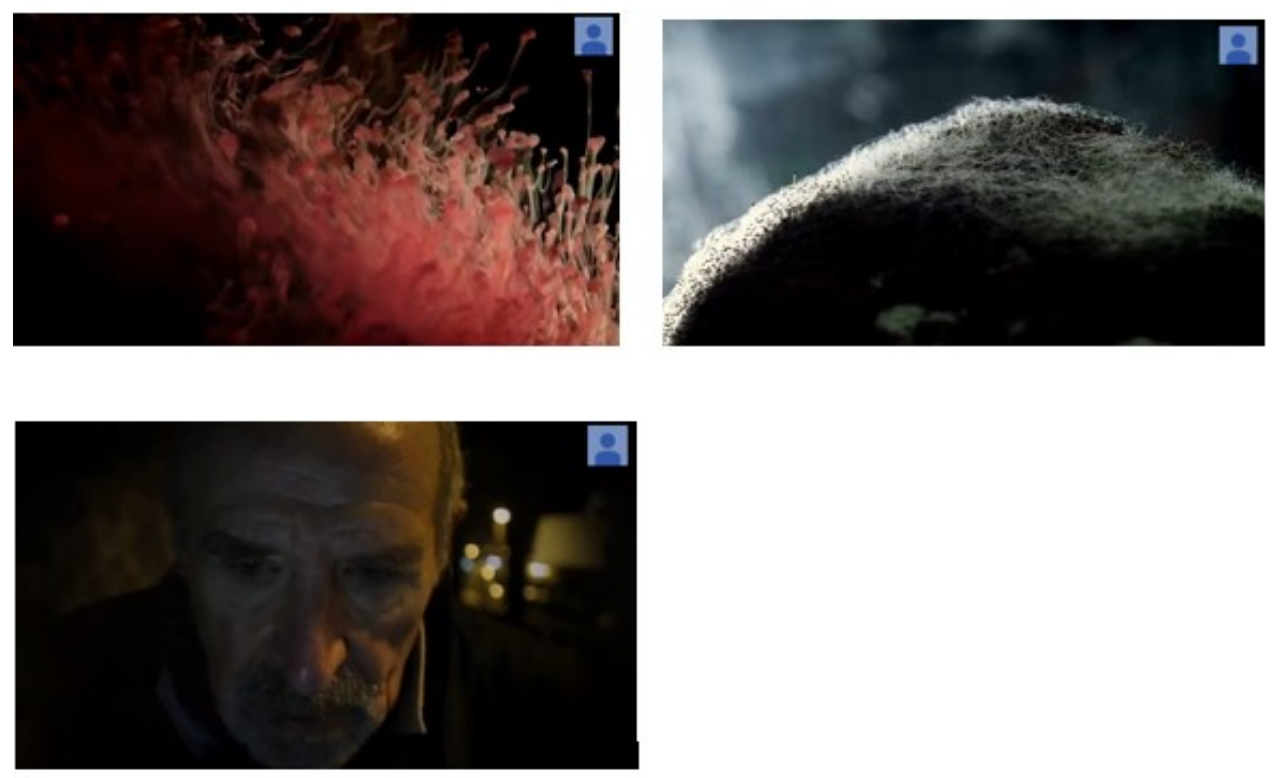

Fig. 7 German advertising film for Caritas - Die Armut (Poverty) (2012) 
In the advertising film "Mercedes - The G-Class", people oppose the forces of nature and thus conquer nature (Fig. 8). Three mountain hikers climb through high snow in the snowy mountains. Suddenly one of them falls into a deep ravine. Secured only on a rope, the mountain hiker hangs in the dangerous ravine. His friends manage to save him at the last moment, but now a storm comes up. The three hikers keep struggling through the snowy landscape towards the summit when they suddenly see a person walking next to them, who reaches the summit, lightly dressed, without mountain gear and without the exertion they have experienced. She drove her way through the mountains to the summit in a Mercedes. With a Mercedes "you get further than you think". Members of internally oriented cultures oppose nature and try to conquer it.
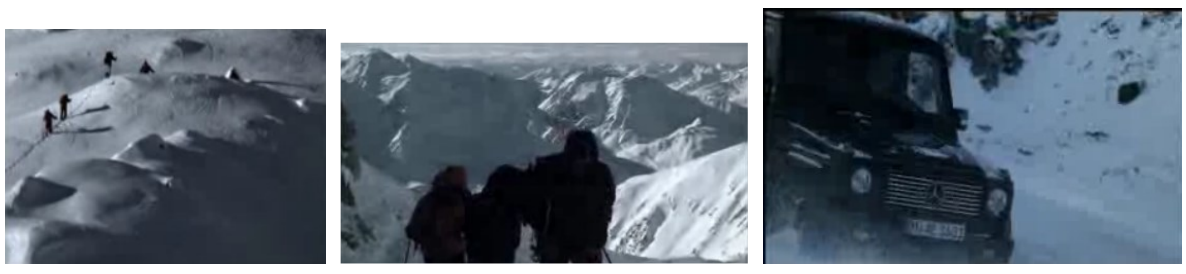

Fig. 8 Advertising film for Mercedes - The G-Class (Weberfilmchen, 2006)

\section{Conclusion}

Fons Trompenaars' and Charles Hampden-Turners's theory (2002) focuses on the thinking and behavioural pattern of people using three basic concepts; relationship with others, time and environment. Considering the areas of coverage of his seven models, and the tradition of other anthopologists, the validity of his theory is widely acceptable. However, there are also limitations to his theory. Trompenaars theory focuses more on global corporate managers, so it doesn't cover individual or group of peoples choices regarding their cultural backgrounds. It can best be applied on a general and professional level.

In summary, it can be said that there are no generally applicable rules for the design of an advertisement. Rather, a multitude of factors would have to be considered in order to successfully advertise a particular product. In addition to cultural peculiarities, product-specific factors and transnational target groups must be taken into account. As a result, the attitude towards the environment can also be recognized by the way the advertising is carried out, the interactions between people and the type of 
people portrayed, as well as the way in which the message is conveyed and the way in which the target group is influenced and reached in different cultures.

\section{References}

Caritas. (2012). Die Armut [Poverty] [Video]. YouTube.

http://www.youtube.com/watch?v=MxEWm7Ml4Fk

Ciucas. (2013). Ciucas - Berea favorita a naturii [Ciucas - Nature's favorite beer]

[Television commercial]. IQads.

https://www.iqads.ro/creatie/30442/ciucas-berea-favorita-a-naturii\#

Hall, T. Edward (1959). The Silent Language. Anchor Books.

Hofstede, Geert (1994). Cultures and Organisations: Software of the Mind. McGraw Hill.

Let's Do It, Romania! (2010). Mustarul [The Mustard] [Television commercial].

IQads. https://www.iqads.ro/creatie/5597/let-s-do-it-romania-mustarul

Schugk, M. (2004). Interkulturelle Kommunikation. Kulturbedingte Unterschiede in Verkauf und Werbung [Intercultural communication. Cultural differences in sales and advertising]. Vahlen Publications.

Treichel, D., \& Mayer, C.-H. (2011). Lebrbuch Kultur. Lehr- und Lernmaterialien zur Vermittlung kultureller Kompetenzen [Textbook culture. Teaching and learning materials to impart cultural skills.]. Waxmann.

Trompenaars, F., \& Hampden-Turner, C. (1996). Riding the Waves of Culture: Understanding Cultural Diversity in Business. John Murray Press.

Trompenaars, F., \& Hampden-Turner, C. (2002). Building Cross-Cultural Competence. Hoboke Publications.

Werbefilmchen. (2006). Die G-Klasse auf den höchsten Bergoipfeln [The G-Class on the highest mountain peaks] [Commercial].

https://www.werbefilmchen.de/selbstgebaut/iframe.php?id=371 